\title{
Factors affecting US Financial Institutions profitability: Empirical Evidence
}

\author{
Melita Charitou* and Petros Lois \\ University of Nicosia, Cyprus.
}

\begin{abstract}
The aim of this study is to assess the major financial factors that affect bank's profitability. To achieve our objective, we used a dataset of more than 2,000 bank-year observations over a six year period. Empirical results using multivariate regression analysis showed that eight financial variables explain bank's profitability. Among the factors that affect positively bank's profitability are net interest margin and capital adequacy ratio (CAR) and amid the factors that affect inversely bank's profitability are the bank's inability to control its operating expenses and the higher riskiness the bank undertakes through increased interest expenses. Overall, these results should be of great importance to bank management, regulators and to the other major stakeholders since by understanding the determinants of the bank's profitability, it will be easier to make better decisions.
\end{abstract}

Keywords: Financial Institutions, profitability, FDIC, Banking, USA.

\section{INTRODUCTION}

According to the Federal Depository Insurance Corporation (FDIC, 2020) $^{1}$, there have been more than 560 financial institutions that filed for bankruptcy from 2001 to 2020, the majority of those being during or around the financial crisis period (2008-2014). Evidence shows that one of the major factors that leads banks to bankruptcy is their inability to maintain a satisfactory level of profits or even worse the occurrence of losses (Liang, Lub, Tsai, and Shiha, 2016). Banks that suffer losses are unable to maintain adequate capital adequacy ratios (CARs), thus leading these financial institutions into increased risk. On the other hand, profitable banks lead to economic growth.

For the aforesaid reasons, researchers examined a number of factors affecting bank's profitability. For example, Hoffmann (2011) examined the determinants of the profitability of the US banks and he showed a negative relationship between the capital ratio and bank's profitability. On the other hand, Zhang and Dong (2011) and Adalessossi and Erdogan (2019), found that there is a positive association between capital ratio and profitability, whereas Pasiouras, Tanna, \& Zopounidis (2008) find that stricter capital requirements improve bank's cost efficiency but decrease its profit efficiency. Beyond capital ratio, researchers also examined the relationship between financial institution's size and profitability. Berger and Humphrey (1997) and Akhavein, Swamy, and

*Address correspondence to this author at Associate Professor of Finance and Accounting, and Dr. Petros Lois is Professor of Accounting, both at the University of Nicosia, Cyprus. Address for correspondence: Division of Finance and Economics, School of Business, University of Nicosia, Cyprus; E-mail: charitou.m@unic.ac.cy

\footnotetext{
${ }^{1}$ https://www.fdic.gov/bank/historical/bank/
}

Taubman (1997) find a positive relationship between financial institution's size and profitability but Goddard et al. (2004) find a negative relationship when examining German and Spanish banks. Zhang and Dong (2011) using US data did not find any association between size and profitability. Thus, there exist inconclusive results regarding the relationship between bank size and profitability. Other researchers examined the association between credit risk and bank's profitability and found an inverse relationship (Miller and Noulas, 1997, Hoffmann, 2011). In contrast, Goddard et.al (2004), using a dataset of banks from European countries provided evidence that there exists a positive association between risk and bank's profitability. As it can be seen, the aforesaid studies provide mixed and inconclusive results.

The aim of this study is to examine a more comprehensive list of factors that affect bank's profitability, among those, factors related to capital adequacy, asset quality \& risk, management effectiveness and size by using a dataset of all US National Commercial financial institutions included in the FDIC. Our study differs from extant research since we use a more recent and relatively large dataset of 2136 bank year observations to examine the aforesaid four major categories of potential determinants of bank's profitability.

Our sample comprises 2136 US bank-year observations over the period 2012-2017. Results of this study show that eight financial variables explain bank's profitability, including five (three) that affect bank's profitability positively (negatively). Among those factors that affect positively bank's profitability are net interest margin and capital adequacy ratio (CAR). On the other hand, amongst the financial variables that affect inversely bank's profitability are the increased riskiness that the bank undertakes, as it is shown by higher interest expenses incurred by the bank as well as the bank's inability to control its operating expenses. 
The remainder of this study is organized as follows. The next section reviews related literature, whereas section 3 describes research design, methodology, dataset and measurement of variables. Empirical results are discussed in section 5. Section 6 concludes the study.

\section{LITERATURE REVIEW AND HYPOTHESIS DE- VELOPMENT}

Evidence shows that there exists a relationship between financial institution's soundness and national economic growth since banks aid in the efficient allocation of resources through the process of serving as a financial intermediary by financing productive business opportunities and investments (Levine and Zervos, 1998). Thus, financial institutions play a vital role in the economy since they have as deposits the savings of the entire economy. If financial institutions are not that profitable and subsequently face financial distress problems, the whole economy will suffer since depositors will lose their savings and at the same time nations have to intervene and pay the deposit insurance (Juca, et al., 2012).

Since profitability is one of the major factors that affects bank's financial soundness, several researchers examined empirically the determinants of bank's profitability using various financial measures, among those, capital adequacy, asset management, efficiency, liquidity, riskiness, bank size and other industry related and macroeconomic measures. Evidence though on the relationship between the aforementioned measures and profitability has been inconclusive.

Using data over the period 1995-2007, Hoffmann (2011) examined the determinants of the profitability of the US banks. Results showed a negative relationship between the capital ratio and bank's profitability, which supports the view that banks do not take advantage of the potentially profitable business opportunities. Also, these researchers provide evidence for a non-monotonic association between the capital ratio and profitability, supporting the efficiencyrisk hypothesis. Moreover, Pasiouras, Tanna, \& Zopounidis (2008) find that stricter capital requirements improve bank's cost efficiency but decrease its profit efficiency.

Beyond capital ratio, researchers also examined the relationship between financial institution's size and profitability. Berger and Humphrey (1997) support that large banks are more efficient than small banks, but it is not that evident whether large banks benefit significantly from scale economies. Akhavein, Swamy, and Taubman (1997) find a positive relationship between financial institution's size and profitability. On the other hand, other researchers support that little cost savings can result from increasing financial institution's size (Berger and Humphrey, 1997), thus leading to scale inefficiencies. Goddard et al. (2004) suggest that the association between the size of a bank's off-balance sheet portfolio and its profitability is positive for UK financial institutions, but negative for German and Spanish banks. Thus, there exist inconclusive results regarding the relationship between bank size and profitability.

Moreover, liquidity and credit risk are additional variables that may affect inversely bank's profitability. For example, financial institutions with high levels of non performing exposures (NPEs) have higher level of loan loss provisions, implying that these loan losses will lead to increased expenses and thus to lower profitability. Miller and Noulas (1997) find a negative relationship between credit risk and profitability (Hoffmann, 2011). Goddard et.al (2004), using a dataset of banks from six European countries over the period 1992-1998 showed that there exists a positive association between risk and bank's profitability, but size had no impact on bank's profitability. Furthermore, Petria et al (2015) examined the determinants of EU bank profitability over the period 2004-2011. Evidence showed that credit, liquidity risk, management efficiency, bank diversification, competition and economic growth affect bank's profitability.

In addition, Zhang and Dong (2011) using US data over the period 2000-2008 found that there is a positive association between capital ratio (equity/total assets), deposits (deposits /total assets), loans (loans/total assets) and bank's profitability but did not find any association between size and profitability. One limitation of this study is that they used capital ratio based on the financial statement information instead of using capital adequacy ratio which takes into consideration Tier I capital and risk weighted assets as per the Basel Accord $(2010,2016)$.

Finally, a more recent study by Adalessossi and Erdogan (2019), using a dataset of 86 banks from eight countries from the West African Economic and Monetary Union over the period 2006-2014, examined bank specific, industry specific and macroeconomic factors that affect bank's profitability. Bank-specific factors examined include measures related to capital, liquidity, efficiency, asset quality and bank size. Based on their dynamic panel GMM first difference model, results showed that the capital ratio, liquidity (liquid assets to total assets), loans to deposit ratio, loans to asset ratio, noninterest income ratio and bank size are positively related to bank's profitability, whereas the cost to income ratio is inversely related to bank's profitability. Evidence showed that liquid assets to deposit ratio and non-performing loans to asset ratio are not statistically significant. As it can be seen, the latter result regarding non performing loans ratio is inconsistent with expectations and extant literature.

To sum up, existing literature regarding the relationship between financial measures and bank's profitability is mixed and inconclusive. The present study differs from extant literature since a) it uses a large number of determinants grouped into four subcategories, namely, capital adequacy, asset quality/risk, management effectiveness, size, and b) it uses a much larger and more recent dataset of US financial institutions.

The following hypothesis will be examined:

H1: There exists an association between bank specific measures (capital adequacy, asset quality \& risk, management effectiveness and size) and bank's profitability.

\section{EMPIRICAL METHODS}

\subsection{Financial Data}

In order to examine the research hypotheses of this study, we collected data for US national financial institutions from the Federal Deposit Insurance Corporation (FDIC) over the sixyear period 2012-17. The final dataset of our financial insti- 
Table 1.

Results below relate to descriptive statistics for all US financial institutions over the period 2012-2017. The dependent variable used is ROA: return on assets, a measure of firm's profitability. Explanatory variables include the following: Ch off Loans: loans coverage of net charge off, Ch_Off_Cover: earnings coverage of net charge off, Prov_Loans: loss allowance to loans, IntExp_TA: interest expense to total assets, NonInt_Exp_TA: non interest expense to total assets, Nimy: net interest margin, Opex_Rev: operating expenses to revenue, CAR_Lev_Ratio: is capital adequacy ratio to leverage, and LnTA: natural logarithm of total assets.

\begin{tabular}{lrrrr}
\hline & N & Mean & Median & $\begin{array}{c}\text { Std. } \\
\text { Deviation }\end{array}$ \\
\hline ROA & 2136 & 0.011 & 0.010 & 0.011 \\
Ch_off_Loans & 2136 & 0.525 & 0.211 & 0.980 \\
Ch_Off_Cover & 2136 & 0.954 & 0.111 & 7.126 \\
Prov_Loans & 2136 & 1.542 & 1.218 & 1.284 \\
IntExp_TA & 2136 & 0.005 & 0.004 & 0.003 \\
NonInt_Exp_TA & 2136 & 0.031 & 0.027 & 0.019 \\
Nimy & 2136 & 0.039 & 0.035 & 0.025 \\
Opex_Rev & 2136 & 0.625 & 0.627 & 0.176 \\
CAR_Lev_Ratio & 2136 & 0.105 & 0.098 & 0.035 \\
LnTA & 2136 & 15.172 & 15.032 & 1.914 \\
\hline
\end{tabular}

Table 2. Correlation Analysis.

Results below relate to Pearson correlation statistics for all US financial institutions over the period 2012-2017. The dependent variable used is ROA: return on assets, a measure of firm's profitability. Explanatory variables include the following: Ch_off_Loans: loans coverage of net charge off, Ch_Off_Cover: earnings coverage of net charge off, Prov_Loans: loss allowance to loans, IntExp_TA: interest expense to total assets, NonInt_Exp_TA: non interest expense to total assets, Nimy: net interest margin, Opex_Rev: operating expenses to revenue, CAR_Lev_Ratio: is capital adequacy ratio to leverage, and LnTA: natural logarithm of total assets.

\begin{tabular}{|c|c|c|c|c|c|c|c|c|c|c|}
\hline & & Ch_off_ & Ch_Off & Prov_L & \multicolumn{3}{|l|}{$x p$} & \multicolumn{3}{|c|}{ CAR_Lev } \\
\hline & ROA & Loans & Cover & oans & TA & Exp_TA & Nimy & Opex_Rev & _Ratio & LnTA \\
\hline$\overline{\mathrm{ROA}}$ & 1.000 & .290 & .023 & .184 & .147 & .351 & .630 & -.542 & .445 & .053 \\
\hline Ch_off_Loans & & 1.000 & -.068 & .660 & 331 & .425 & .615 & -.087 & .279 & .022 \\
\hline Ch_Off_Cover & & & 1.000 & -.074 & -.040 & -.087 & -.070 & -.103 & .005 & .007 \\
\hline Prov_Loans & & & & 1.000 & 200 & .286 & .452 & .031 & .250 & -.122 \\
\hline IntExp_TA & & & & & 1.000 & 137 & .309 & -.117 & .204 & -.049 \\
\hline Nonlnt_Exp_TA & & & & & & 1.000 & .496 & .348 & .195 & -.116 \\
\hline Nimy & & & & & & & 1.000 & -.252 & .307 & -.046 \\
\hline Opex_Rev & & & & & & & & 1.000 & -.221 & -.194 \\
\hline CAR_Lev_Ratio & & & & & & & & & 1.000 & -.109 \\
\hline LnTA & & & & & & & & & & 1.000 \\
\hline Number of obs & 2136 & 2136 & 2136 & 2136 & 2136 & 2136 & 2136 & 2136 & 2136 & 2136 \\
\hline
\end{tabular}

tutions consists of 2136 firm-year observations. Initial dataset had more observations, but consistent with prior studies we excluded banks that did not have data for our dependent and independent variables and winsorized variables with extreme observations (absolute studentized residuals 2).

\subsection{Statistical Models in Explaining Bank's Profitability}

Since our hypothesis relates to the factors that affect the financial institution's profitability, we will use the following multiple regression model to test this hypothesis:

$\mathrm{ROA}=\omega_{0}+\omega_{1} *$ Ch_off_Loans $+\omega_{2} *$ Ch off Cover $+\omega_{3}$ $*$ Prov_Loans $+\omega_{4} *$ IntExp_TA $+\omega_{5} *$ NonInt_Exp_TA + $\omega_{6} *$ Nimy $+\omega_{7} *$ Opex_Rev $+\omega_{8} *$ CAR_Lev_Ratio $+\omega_{9} *$ $\operatorname{LnTA}+\mathrm{e}_{\mathrm{it}}$

In the above model, $\omega_{0}$ and $\omega_{\mathrm{i}}$ denote the intercept term and the slope coefficients, respectively, $\mathrm{e}_{\mathrm{i}}$ denotes the error term.
The dependent variable used is ROA: return on assets, a measure of firm's profitability. Explanatory variables include the following: Ch_off_Loans: loans coverage of net charge off, Ch_Off_Cover: earnings coverage of net charge off, Prov_Loans: loss allowance to loans, IntExp_TA: interest expense to total assets, NonInt_Exp_TA: non interest expense to total assets, Nimy: net interest margin, Opex_Rev: operating expenses to revenue, CAR_Lev_Ratio: is capital adequacy ratio to leverage, and LnTA: natural logarithm of total assets.

\section{EMPIRICAL RESULTS}

\subsection{Descriptives}

In order to test our research proposition which relates to the factors affecting bank's profitability, we present in Table $\mathbf{1}$ descriptive statistics for all dependent and explanatory variables used in the regression model. 
Evidence shows that US financial institutions have positive profitability (ROA) over the period 2012-17. Specifically, bank's mean and median ROA has been $1.1 \%$ and $1 \%$, respectively. The mean values for charge-off loans and charge off coverage are $52.5 \%$ and $95.4 \%$, respectively. Moreover, the mean values of the interest expense to total assets and non-interest expense to total assets are $0.5 \%$ and $3.1 \%$, respectively. The mean value of the loss allowance to loans has been 1.542 and the mean capital adequacy ratio to leverage is $10.5 \%$. Moreover, the mean of the net interest margin (nimy) is $3.9 \%$, which indicates that the lending rates of the US financial institutions is $3.9 \%$ greater compared to their borrowing rate. Finally, the operating expense ratio to revenues is $62.5 \%$, indicating that the profit margin of the financial institutions is $37.5 \%$.

Beyond the aforesaid descriptive statistics, in Table 2 we present correlation analysis results between all variables used in our multivariate regression models. Results show that the variables that relate mostly to Return on Assets (ROA) are net interest margin (nimy) and the ratio of operating expenses to revenues. Results indicate that the greater the difference between the interest charged to clients and interest paid to depositors, the greater the bank's profitability (correlation $63 \%$ ). Moreover, correlation analysis results show that the greater the bank's operating expense ratio (Opex_Rev) the lower the bank's profitability (correlation $-54.2 \%$ ).

Furthermore, results show that the greater the bank's capital adequacy ratio (CAR_Lev) the greater the bank's profitability (correlation $44.5 \%$ ). In general, banks with higher CARs are on average healthier. Moreover, correlation analysis results show that the greater the following four variables the higher the bank's profitability: loans coverage of net charge off (ch_off_loans), loss allowance to loans (Prov_loans), interest expense (int_exp) and non interest expense ratios (nonint_exp_TA). Specifically, the pearson correlations be- tween these four variables and profitability are $29 \%, 18.4 \%$, $14.7 \%$ and $35.1 \%$, respectively.

As far as correlation between the explanatory variables is concerned, evidence shows that the greater correlation exists between charge off loans and loss allowance to loans (prov_loans), which is $66 \%$. Also, the correlation between net interest margin (nimy) and loans coverage of net charge off (ch_off_loans) is $61.5 \%$, a result indicating that the greater the loans coverage of net charge offs the greater the bank's net interest margin and thus the greater the bank's profitability.

\subsection{Multivariate Regression Results}

As already discussed, the aim of this study is to examine the factors that affect bank's profitability. For this purpose, we will use the following model.

ROA $=\omega_{0}+\omega_{1} *$ Ch_off_Loans $+\omega_{2} *$ Ch_off_Cover $+\omega_{3}$ $*$ Prov Loans $+\omega_{4} *$ IntExp_TA $+\omega_{5} *$ NonInt_Exp_TA + $\omega_{6} *$ Nimy $+\omega_{7} *$ Opex_Rev $+\omega_{8} *$ CAR_Lev_Ratio $+\omega_{9} *$ LnTA + eit

Table 3 presents multiple regression analysis results on the relationship between profitability and nine explanatory variables for 2136 US financial institutions over the period 2012-17. According to the F-statistic, results in this table indicate that at least one of the explanatory variables is different from zero and thus these variables explain bank's profitability. The F-value of the regression model is 583,489 and statistically significant with $\mathrm{p}$-value $=0.000$. The Fvalue in this multivariate regression model is the result of a test where the null hypothesis is that all regression coefficients in this model are equal to zero. The F-test compares the results of the reduced model with only the constant and the full model that includes all nine explanatory variables. A statistically significant $\mathrm{F}$ is an indication that the added explanatory variables improve the reduced model.

\section{Table 3. Regression Analysis.}

Results below relate to multivariate analysis statistics for all US financial institutions over the period 2012-2017. The dependent variable used is ROA: return on assets, a measure of firm's profitability. Explanatory variables include the following: Ch_off_Loans: loans coverage of net charge off, Ch_Off_Cover: earnings coverage of net charge off, Prov_Loans: loss allowance to loans, IntExp_TA: interest expense to total assets, NonInt_Exp_TA: non interest expense to total assets, Nimy: net interest margin, Opex_Rev: operating expenses to revenue, CAR_Lev_Ratio: is capital adequacy ratio to leverage, and LnTA: natural logarithm of total assets.

\begin{tabular}{lrrrrr}
\hline & $\begin{array}{c}\text { Unstandardized } \\
\text { coeffiicients }\end{array}$ & Std. Error & t-value & $\begin{array}{c}\text { statistical } \\
\text { significance }\end{array}$ & $\begin{array}{c}\text { Collinearity } \\
\text { VIF }\end{array}$ \\
\hline (Constant) & 0.013 & 0.001 & 8.591 & 0.000 & \\
Ch_off_Loans & -0.002 & 0.000 & -11.55 & 0.000 & 2.517 \\
Ch_Off_Cover & $1.29 E-05$ & 0.000 & 0.735 & 0.462 & 1.023 \\
Prov_Loans & 0,001 & 0.000 & 1.897 & 0.058 & 1.919 \\
IntExp_TA & -0.188 & 0.039 & -4.858 & 0.000 & 1.169 \\
NonInt_Exp_TA & 0.251 & 0.009 & 26.445 & 0.000 & 2.083 \\
Nimy & 0.144 & 0.008 & 18.846 & 0.000 & 2.409 \\
Opex_Rev & -0.035 & 0.001 & -37.59 & 0.000 & 1.806 \\
CAR_Lev_Ratio & 0.059 & 0.004 & 14.867 & 0.000 & 1.234 \\
LnTA & $0, .001$ & 0.000 & 2.644 & 0.008 & 1.107 \\
\hline F-value & 583.500 & & .000 & & \\
Rsquared & $71.10 \%$ & & & & \\
Number of Obs & 2136 & & & & \\
\hline
\end{tabular}


Results also show that the $\mathrm{R}^{2}$ is $71.1 \%$, indicating that these nine explanatory variables included in the model explain $71.1 \%$ of the variation in the bank's profitability. Evidence shows that eight out of the nine explanatory variables used in the model are statistically significant. Specifically, five of those bank financial variables affect positively firm's profitability whereas three of those affect inversely bank's profitability. Specifically, the coefficients of the following five variables are positive and statistically significant: loss allowance to loans (prov_loans), non interest expense to total assets (nonint_exp_TA), net interest margin (nimy), capital adequacy ratio to leverage (CAR_Lev_ratio) and firm size as measured by $\operatorname{Ln}(\mathrm{TA})$. The coefficient of loss allowance to loans (prov_loans) is positive (0.001) and statistically significant with $\bar{p}$-value $=0.058$. The coefficient of non-interest expense to total assets (nonint_exp_TA) is 0.251 and highly statistically significant ( $\mathrm{p}$-value $=0$ ). Same applies for net interest margin (nimy) and capital adequacy ratio to leverage (CAR_Lev_ratio) since both variables are highly statistically significant with p-values at 0 and with coefficients equal to 0.144 and 0.059 , respectively. The coefficient of net interest margin indicates that an increase in net interest margin by $1 \%$ leads to an increase in ROA by 0.144 , whereas an $1 \%$ increase in CAR as a \% of Leverage leads to 0.059 increase in ROA. Finally, firm size as measured by LnTA is positive and highly statistically significant ( $\mathrm{p}$-value $=0.008$ ), indicating that larger banks are on average more profitable compared to smaller financial institutions possibly due to the economies of scale.

There are also explanatory variables that affect inversely bank's profitability. These are: loans coverage of net charge off (ch_off_loans), interest expense as a \% of total assets (intexp_TA), and operating expense as a $\%$ of revenues (opex_rev). Specifically, the coefficient of loans coverage of net charge off (ch_off_loans) is -0.002 and highly statistically significant $(\mathrm{p}$-value $=0.000)$, indicating that a $1 \%$ increase in loans coverage of net charge off will lead to -0.002 decrease in ROA. Also, the coefficient of interest expense as a $\%$ of total assets (intexp_TA) is -0.188 and highly statistically significant ( $\mathrm{p}$-value $=0.000)$. Finally, the coefficient of operating expense as a \% of revenues (opex_rev) is -0.035 and highly statistically significant, indicating that a $1 \%$ increase in operating expenses as a $\%$ of revenues will lead to a decrease in ROA by -0.035 .

Furthermore, the properties of this multivariate analysis model were tested, among those to determine if there is collinearity between the explanatory variables. To do so, we examined the Variance Inflation Factors (VIFs). Results in table 3 show that the maximum VIF is 2.517 , indicating that there is no problem with multicollinearity between the explanatory variables. Econometrics theory and practice states that in order to be a problem, the VIFs should be greater than 10 (Min, 2019). In summary, evidence presented in this study indicates that eight explanatory variables can be used to explain financial institutions' profitability.

\section{CONCLUSIONS}

In this study we hypothesized that a number of bank's financial variables can be used to explain bank's profitability. To test this hypothesis, we used a dataset of 2,316 bank-year observations over the period 2012-17. Multivariate analysis results showed that eight financial variables can be used to explain bank's profitability, five (three) of those affecting positively (inversely) bank's profitability. Interestingly, two of those variables that affect positively bank's profitability are the net interest margin and Capital adequacy ratio (CAR). Banks that manage to have a greater margin between lending and borrowing rates are more profitable as well as those banks that manage to maintain higher capital adequacy ratios, possibly because these banks are able at the same time to gain the trust of their investors and raise additional funds to cover risk weighted assets. On the other hand amongst the financial variables that affect inversely bank's profitability are interest expense as a \% of total assets (intexp_TA), and operating expense as a $\%$ of revenues (opex_rev). Thus, the greater the interest expense, meaning that the bank has probably undertaken higher risk, the lower the bank's profitability. Also, banks that do not manage to control their operating expenses, as indicated by the ratio of operating expenses to revenues, are expected to have lower profitability.

Overall, the results of this study should be of great importance to bank management, regulators and to the major stakeholders such as investors and financial analysts, since by understanding the determinants of the bank's profitability, it will be easier to make better decisions.

\section{CONFLICT OF INTEREST STATEMENT}

The authors declare that they have no conflict of interest.

\section{REFERENCES}

Adalessossi K and E Erdogan (2019), Analysis of factors influencing bank profitability: Evidence from the West African Economic and Monetary Union Banking Sector, Journal of Accounting, Finance and Auditing Studies, vol 5.1, pp. 122-154.

Akhavein, J., P. Swamy and S. Taubman (1997), 'A general method of delivering the efficiencies of banks from a profit function', Journal of Productivity Analysis, 8, 71-93.

Basel Committee on Banking Supervision (BCBS) (2010). Basel III: A global regulatory framework for more resilient banks and banking systems. Basel Committee on Banking Supervision, Basel.

Basel Committee on Banking Supervision (BCBS) (2016), Guidance on the application of the Core Principles for Effective Banking Supervision to the regulation and supervision of institutions relevant to financial inclusion.

Berger, A. and D. Humphrey (1997), 'Efficiency of financial institutions: International survey and directions for future research', European Journal of Operational Research, 98, 175-212.

Financial Depositary Insurance Corporation, FDIC, (2020), https://www.fdic.gov/bank/historical/bank/

Goddard, J., P. Molyneux and J. Wilson (2004), 'The profitability of European banks: A cross-sectional and dynamic panel analysis', The Manchester School, 72, 363-81.

Hoffmann Paolo, (2011), Determinants of the Profitability of the US Banking Industry, International Journal of Business and Social Science, Vol. 2 No. 22; December 2011

Juca, M., A. Sousa, and A. Fishlow, (2012). Capital Structure Determinant's of North American Banks and the Compensation Executive Program: An Empirical Study on the Actual Systemic Crisis. International Journal of Business and Management, 7(17), 3-26.

Levine, R. and S. Zervos (1998), Stock Markets, Banks, and Economic Growth. The American Economic Review, Vol. 88, No. 3 (Jun., 1998), pp. 537-558 (22 pages)

Liang D., C. Lub, C. Tsai, and G. Shiha (2016), Financial ratios and corporate governance indicators in bankruptcy prediction: A comprehen- 
sive study, European Journal of Operational Research, Volume 252, Issue 2, 16 July 2016, Pages 561-572

Miller, S. and A. Noulas (1997), 'Portfolio mix and large-bank profitability in the USA', Applied Economics, 29, 505-12.

Min, C., Applied Econometrics (2019), Taylor and Francis Publishers, $1^{\text {st }}$ ed. London.

Pasiouras, F., Tanna, S., \& Zopounidis, C. (2009). Banking regulations, cost and profit efficiency: Cross-country evidence, International Review of Financial Analysis 18(5):294-302
Petria N, B. Capraru and I. Ihnatov (2015), Determinants of banks' profitability: evidence from EU 27 banking systems, Procedia Economics and Finance 20, pp. 518-524.

Zhang C., and L. Dong (2011), Determinants of bank profitability. Evidence from the US banking sector, Beedie School of Business, Simon Fraser University.

Received: Dec 03, 2020

Copyright $($ 2020- All Rights Reserved

This is an open-access article. 